\title{
Coping with change: the implications of e-commerce adoption for island consumers
}

\author{
by \\ Paul Freathy* \\ and \\ Eric Calderwood
}

Institute for Retail Studies

Stirling Management School

University of Stirling

Stirling

Scotland

FK9 4LA

j.p.freathy@stir.ac.uk

eric.calderwood@stir.ac.uk

*Contact author 


\title{
Coping with change: the implications of e-commerce adoption for island consumers
}

\begin{abstract}
This paper examines the implications of e-commerce for retailers on three Scottish island groups. These locations are amongst the most economically fragile regions of the UK. The extensive use of e-commerce by residents has reconfigured traditional shopping patterns. The paper argues that this pattern of spending represents a form of 'trade leakage' with increased monies being spent off the island. The reaction from local retailers to this threat appears limited. The paper highlights the consequences for the local economy and suggests a more proactive response is needed in order to meet the challenges posed by internet availability.
\end{abstract}

Keywords

Island Retailing

Internet

Consumer Behaviour

Rural Communities

Scotland

JEL Codes

E21 - Consumption

L81 - Retail and Wholesale Trade

L86 - Information and Internet Services

R1 - General Regional Economics 


\section{Coping with change: the implications of e-commerce adoption for island consumers}

1. Introduction

The value and importance of Information and Communications Technologies (ICT) to the growth and sustainability of rural areas has been widely noted. For those individuals who are in a position to enjoy its advantages, new technology has the potential to usher in a 'new form of society' (Richards, 2004: 230). Such a view is clearly articulated in the Scottish Government's Structural Funds Operational Programme 2007 - 2013 (SCOTTISH GOVERNMENT, 2008) which maintains that a strong telecoms infrastructure is critical in encouraging both economic and social development. A similar view is re-iterated by the SAC (2012) who note the importance of high speed broadband in enabling rural businesses to function effectively. Future competitive advantage seems premised upon the ability of firms to adopt, integrate and take advantage of the opportunities afforded by a range of evolving technologies.

While on one level technology has an enabling capacity that can provide rural businesses with an exposure to new customer groups, new channels of delivery and the ability to compete in new markets, a number of commentators have questioned the extent to which high speed internet services offer a solution to the identified issues of rural economic decline. Galloway for example questions the ability of rural businesses to fully exploit the potential offered by ICT (GALLOWAY, 2007, GALLOWAY et al., 2011). If firms are unable to capitalise upon its potential, such technologies could be counter productive and 
paradoxically, constitute a real threat to business performance by undermining existing markets and customer segments.

This paper will argue that such a situation is evidenced in the Scottish isles where technology has simultaneously empowered consumers and increased market competition. It will detail the impact of e-commerce upon the shopping behaviour of island residents and consider the impact of these changes upon local retail businesses as well as the broader regional economy. Through a quantitative survey of island residents and a series of follow up in-depth interviews, the paper will detail how traditional shopping patterns have been reconfigured by the extensive use of e-commerce. Consumers purchase a wide range of goods on-line and while residents still visit the main town, these trips are primarily to shop for grocery items. Patterns of non food shopping remain more diverse with respondents using a variety of retail channels including the internet, local stores and trips to the mainland.

This paper also maintains that the competitive response from local retailers appears limited and that a more proactive reaction is needed in order to meet the demands posed by internet availability. Operating an island provides a series of unique challenges and many businesses continually struggle to remain competitive in the face of diminishing populations, increased competition and rising costs (CALDERWOOD, and FREATHY, 2011; GALLOWAY et al., 2011; MOCHRIE et al 2006; SCOTTISH GOVERNMENT, 2008). A failing retail sector is seen to further weaken an already fragile and vulnerable regional economy.

To achieve the above aims, the paper is divided as follows; first, a contextual framework details the different economic challenges facing Scottish islands. This is followed by a brief discussion of island retailing. After the methodology is outlined, the empirical research 
details how consumer shopping patterns and purchasing habits have changed. Finally a series of conclusions are drawn on the implications of these findings for the retail sector and the island economy as a whole.

2. Economic development and the Scottish Isles

While island groups can differ markedly from each other, they are also subject to a common range of constraints due to their relative insularity. Their economies are often considered vulnerable as they are based upon a limited range of commercial activities or are subject to seasonal fluctuations (GUILLAUMONT, 2010; ROBERTS, 2005; ROYALE 2001;

SELVADURAI et al., 2011). While rural policy makers have encouraged industrial diversification or multiple specialisations (ROBERTS 2005; WEBBER et al., 2009) research has identified that the Scottish islands are amongst the most disadvantaged and economically fragile regions in the UK (SCOTTISH GOVERNMENT, 2008; 2010; COPUS and CRABTREE, 1992). This fragility has been argued to be the outcome of a number of factors including the remoteness of many communities, a poor support and transport infrastructure as well as low levels of economic activity (RICHARDS 2004; ROBERTS 2005; SCOTTISH GOVERNMENT, 2008).

While in-migration and counter urbanisation has had some rejuvenating effects (BOYLE, 1997; COPUS and CRABTREE, 1996; STOCKDALE, 2010; STOCKDALE et al., 2000), many island communities have witnessed population decline, decreases in the number of businesses trading and increases in the levels of unemployment. For example, the SAC (2012) maintain that by 2035 the number of persons living in the Outer Hebrides is projected 
to decline by over $11 \%$, (those of working age are predicted to fall by $19.5 \%$ ). Such population decreases have a number of social and economic consequences. KILKENNY (2010) argues that outward migration reduces the efficiency and productivity of island communities and serves to directly constrain regional development by limiting the fiscal capacity of those who remain (see also COURTNEY et al., 2008).

KILKENNY (2010) also maintains that employment is one of the primary means of generating growth in rural areas. A review of the Scottish islands reveals that employment is often part time and seasonal and, reflecting the concentration upon primary industries (fishing, agriculture and forestry), is either low paid or highly specialised (ROBERTS and THOMSON, 2003; SCOTTISH GOVERNMENT, 2008). Secondary employment is widespread and individuals are most likely to work in small enterprises. Although previous studies have suggested that rural areas are attractive to entrepreneurs (KEEBLE and TYLER 1995), the limited number of businesses that have head or regional offices on the islands restricts the number of managerial positions.

For those firms who are located on the islands a number of constraints inhibit their growth and development. For example, FREATHY and CALDERWOOD (2011) noted the size of the local markets and distance to major conurbations constrained business expansion. Similarly, the SCOTTISH GOVERNMENT (2008) acknowledge that an inadequate transport infrastructure remains a major obstacle to economic development. The rail network is identified as deficient, while ferry links are subject to seasonal fluctuations in frequency. In addition, both air and sea carriage are considered relatively expensive. Business to business opportunities also remain limited due to the insufficient number of enterprises in many rural areas, a factor which in turn serves to further restrict innovation (MOCHRIE et al., 2006). Those individuals who do operate island businesses often lack equity capital, have limited 
managerial skills and do not have access to training, advice or guidance networks (KILKENNY, 2010; SCOTTISH GOVERNMENT, 2008).

While for some island businesses ICT developments and broadband availability have undoubtedly provided the opportunity to expand into new markets, GALLOWAY (2007) argues that the policy of 'technological push' advocated in a number of Government policies misunderstands the nature of rural businesses ${ }^{\mathrm{i}}$. While ICT adoption is less prevalent amongst rural businesses, there is little evidence to suggest that improved access to a technological infrastructure will encourage increased usage. GALLOWAY (2007) maintains that other, non technical factors inhibit adoption. It is argued that many small rural firms display low levels of entrepreneurial drive and exhibit little proclivity for economic growth. In addition, businesses often demonstrate a propensity for inertia and a desire to maintain the status quo (GALLOWAY et al., 2011; MOCHRIE et al., 2006). Similarly, RICHARDS (2004) concluded that rural SME's saw IT as a tool where the costs of acquiring the skills to harness its potential outweighed any benefits.

Levels of technological adoption by rural firms cannot however be solely attributed to lethargy and indifference. Part of the unwillingness to invest in technology may be linked to the fact that businesses often lack an export market. As MOCHRIE et al., (2006) identify, many firms are location specific and offer services that are focussed upon meeting local needs. While ICT may provide the opportunity to access global markets this option has limited relevance to the majority of businesses (GALLOWAY et al., 2011).

\section{Island retailing}


Bodies such as the Scottish Agricultural College (SAC), the Rural Development Commission (RDC) and the Carnegie Trust have all highlighted the practical difficulties of creating a retail presence in remote and sparsely populated locations (CARNEGIE 2007, 2008; RDC 1994; SAC, 2012). The levels of retail degeneration in rural areas and the closure of many businesses has been attributed to a number of factors including the growth of large multiple retailers, the decline of post offices as well as changing patterns of consumer purchase behaviour (BROADBRIDGE AND CALDERWOOD, 2002; COMMISSION FOR RURAL COMMUNITIES, 2006; McEACHERN and WARNABY, 2006; SCARPELLO et al., 2009). Across individual islands and island groups current retail provision is not uniform and the sector displays significantly spatial differences. For example, larger islands with market towns such as Kirkwall (Orkney), Lerwick (Shetland) and Stornoway (Lewis and Harris) have an established retail sector often with intense competition between local and national retailers. On other, more remote islands, communities may be serviced by a single, multifunctional retail outlet, community shop or social enterprise (CALDERWOOD and DAVIES 2012). Traditionally the goods offered through these physical stores have been supplemented by a range of other retail channels such as catalogues, mobile shops and product fairs.

\section{Table 1 about here}

Table 1 details the number and type of retail stores operating in each of the three main towns on Orkney, Shetland and the Outer Hebrides. While some business offer an eclectic mix of products that place them in more than one category (e.g. one garden centre offered a small selection of pet related products), the table illustrates how certain product groups are serviced by only one or two retail providers. While grocery provision in each of the towns is supported by the major multiples and a number of small independents, consumers had a more limited 
choice when purchasing sports goods, music, electrical appliances and kitchen and bathroom items. Moreover, what Table 1 does not demonstrate is the restricted merchandise assortment available in a number of these stores. For example, the product range of one photography store was limited as the physical space was jointly shared the with a jewellery retailer.

Operating a retail business on an island provides firms with a number of unique challenges. CALDERWOOD, and FREATHY (2011) for example note the complexity of the supply chain for perishable goods. They identified that the distance to market and the limitations of the transport infrastructure increased the amount of product handling, led to longer lead times and reduced the shelf life of fresh items. Given that the majority of goods are delivered by sea, ferry crossings were subject to prevailing weather conditions and as a consequence both quality and availability could be further affected (see also BYROM et al., 2001, 2003). More fundamentally, trading on an island incurs higher operational costs. ARMSTRONG et al., (1991), maintained transportation, fuel, staffing and waste disposal were all more expensive than on the mainland and that such costs could add over $4 \%$ to total freight expenditure (BINET and WILSON, 1997; OFT 2012; PRENTICE 1992). Table 2 provides a price comparison between on-line providers and island stores. It details a randomly selected basket of ambient, branded products sold on-line, through a retail multiple in the main town and via an independent store approximately 30 miles from the urban centre.

\section{Table 2 about here}

Although Table 2 is provided only for illustration and does not take into account issues such as price promotions, the option to purchase own brand nor the cost of carriage to the islands, 
it does highlight significant price disparities. While on-line purchases represent the cheapest overall option, to gain the benefits of e-commerce, consumers are often required to place a minimum order. This involves both a larger initial, financial outlay and the space to accommodate bulk purchases. Table 2 also suggests that a marked price differential exists between different island retailers with the national chain being approximately $13 \%$ cheaper than the smaller independent.

From a consumer perspective, previous research has identified a number of retail related concerns amongst island residents. A SHETLAND ISLANDS report (2004) noted dissatisfaction with local retail provision and highlighted how respondents considered the local market to be expensive, while at the same time offering poor quality products and limited levels of customer service. Despite a willingness to utilise alternate channels (e.g. product catalogues, mainland shopping, mobile shops) a lack of choice had meant that individuals have often been compelled to rely upon local retail provision.

While early research identified a reluctance towards technological adoption amongst rural consumers (SCOTTISH EXECUTIVE, 2001), FREATHY and CALDERWOOD (2013) identified that island residents extensively used the internet for the provision of goods and services. Their exploratory study identified a wide range of goods and services purchased on-line with consumers using the internet to overcome the limitations of choice, availability and price. Although e-commerce represents a form of disintermediation that has reconfigured traditional shopping patterns and materially improved the lives of island residents, its widespread adoption has a number of consequences for local businesses. For example, unless individuals choose to use local web-sites, e-shopping may represent a form of 'trade leakage' whereby monies previously spent on the island are spent elsewhere (Lee et 
al., 2009). While the propensity of individuals to 'outshop' is again not new (PRENTICE, 1992), the range of benefits afforded by e-commerce may serve to accelerate this trend. Moreover, the potential of e-commerce to reconfigure shopping patterns may mean island businesses are frequented less often, used only for 'top up' and distress purchases or avoided completely. Such leakages have the potential to reduce both sales and profit levels and, at a broader, regional level, undermine growth in the local economy (Courtney et al., 2008).

\section{Methodology}

For this study the Scottish island groups of Orkney, Shetland and the Outer Hebrides were chosen. The Scottish Government's Urban /Rural Eight Fold Classification 2011-2012 (SCOTTISH GOVERNMENT, 2012) categorises each of these locations as being 'Very Remote Rural ${ }^{\mathrm{ii}}$ with each having a single 'Very Remote Small Town' (a population of between 3,000 and 10,000). The remoteness of these island groups is further illustrated by their proximity to major urban conurbations. For example, the Orkney isles are the nearest of the three groups to the mainland with a 90 minute crossing between Stromness and Scrabster. However to visit the nearest large town (Inverness) requires an additional 240 mile round trip. Similarly the journey between Stornoway (Outer Hebrides) to Inverness includes a ferry crossing, a 120 mile round trip and takes approximately 9 hours. The ferry crossing from Lerwick in the Shetland isles is direct to the city of Aberdeen but takes twelve and a half hours. In the context of this research, the remoteness of these towns help identify the impact that internet shopping has upon specific locations.

Each of the three Scottish groups used in this study are comprised of a number of islands that vary in size, population, and level of commercial provision. For example, Lewis / Harris in the Outer Hebrides has a population of just under 20,000, is approximately 79 miles in length 
and a mix of local and national retailers. In contrast, Papa Stour in the Shetland Isles has a population of 23, just over 3 miles of tracked road and no store. Consumers therefore have different levels of access to goods and services depending upon which island they live. To identify whether this accessibility influenced patterns of shopping behaviour and internet usage, each island was first categorised according to its level of retail provision (Table 3).

\section{Table 3 about here}

The first category (Type One) comprises those islands large enough to sustain a national multiple presence and due to their size, accommodate a variety of organisational forms (convenience stores, supermarkets and superstore) and fascias. Typically these islands have both an urban and rural catchment area as well as a number of independent retail operators. Whilst having a population that can sustain a retail presence, a number of smaller islands around the Scottish coast have no national multiples and are serviced by one or more independent operator, a community group or a social enterprise (Type Two). These businesses often support smaller, more dispersed island communities and may occupy multiple roles (BYROM et al., 2001; FREATHY and CALDERWOOD, 2011). Finally, despite having a permanent population, a small number of Scottish islands have no established retail provision. These communities rely upon products being ordered and transported by boat from the larger islands or the mainland (Type Three). By providing this categorisation the research will determine whether internet shopping behaviour varies by the level of retail provision island type and the implications for the retailers that serve these communities.

Table 4 about here 
Altogether 2077 questionnaires were distributed to resident households across the three island types (Table 4). FREATHY and CALDERWOOD (2013) identified that internet availability was most likely to have reconfigured shopping behaviours in more remote island communities. In order to identify any spatial patterns in e-shopping, questionnaires were distributed at varying distances to the main town (due to the size of scale of the Type Two and Three locations this exercise was limited to Type One islands). Where possible, questionnaires were distributed at the mid-point in each category (for example at the 15 minute point in the 10 minute - 20 minute category). However in some of the more remote island locations communities were dispersed over a broader area and as a consequence the drive times had to be expanded in each category. In addition, no Type Two islands were surveyed on the Outer Hebrides. Although islands such as Scalpay and Bernera were previously separated from the main island, these are now connected by causeways that allow vehicle access and therefore do not fit the research criteria.

The questionnaire itself was divided into six sections. In addition to gathering demographic data and establishing their level of internet connectivity, the research identified the extent to which island residents shopped on-line and their reasons for doing so. Respondents were also questioned as to which products they most likely to purchase via the internet and their choice criteria for selecting an on-line provider. The research then examined the impact of the internet upon shoppers mobility patterns as well as their opinions of local retailers and their islands main urban area. Altogether 396 responses were received by the closing date of which 388 were usable (Table 5). All data were coded and analysed using SPSS.

Table 5 about here 
Due to the complexity of consumer shopping patterns and the relatively small sample sizes on Type Two and Three islands, qualitative interviews were also held with 39 island residents (approximately $10 \%$ of those who had participated in the quantitative research phase) (Table 6). Individuals were selected at random having previously indicated that they would be willing to participate further in the research. On Type One islands respondents from each of the five drive time categories were interviewed. The aim was to build upon the previous stage of the research and answer specific issues identified in the quantitative research phase. Respondents were asked to expand upon particular points, reaffirm specific facts and confirm the accuracy of the information supplied.

Table 6 about here

Altogether over 19 hours of qualitative research material was recorded. All interviews were conducted by telephone and data were subsequently transcribed and analysed with key themes being identified through the use of established content techniques (HSIEH and SHANNON 2005). Each individual narrated their own personal shopping experiences and expanded upon issues identified in the quantitative research phase. The research aimed to construct a picture of how individuals shopped and to identify specific patterns of internet usage across a variety of locations and range of product categories.

This research has a number of limitations. First, no attempt is made to differentiate between the island groups. The retail sectors across the three locations are viewed homogenously. As a consequence, any inter-island differences are not detailed or discussed. Second, the research provides an essentially demand side perspective that does not examine either the 
reaction or the views of the retailers themselves. While this paper details consumer attitudes to local retail provision, it does not provide an insight into how individual businesses have reacted. Any strategic initiatives undertaken by firms to counter the challenge of e-commerce lies outside the remit of this paper and are not detailed. This is not to suggest a supply side perspective is unimportant rather it represents a further stage in this research process.

\section{Findings}

The research identified that broadband provision on the islands was widespread and that internet usage amongst respondents was high with $95 \%(n=351)$ maintaining that they had on-line access and $92 \%(n=341)$ having a broadband connection. Only $6 \%$ of respondents stated that they had not accessed the internet over the past month while $85 \%$ maintained they had made at least one on-line transaction during that period. Individuals were asked to identify the primary reason for shopping on-line, these were identified as Price $(33.2 \%)$ Convenience (25.3\%) and Range (24.2\%). In addition, over $90 \%$ of respondents considered the internet to be an important way of remaining better informed and gathering information prior to purchase (Table 7).

\section{Table 7 about here}

Such findings are perhaps not surprising and reinforce the significant body of existing research into the benefits of internet adoption for consumers in rural areas (FREATHY and CALDERWOOD, 2013; MALECKI, 2003; RAO HILL et al. 2011).

Previous studies have identified how channel choice varies by the types of goods and services being purchased (e.g. LEEUWEN and RIETVELD, 2011). Given its perceived benefits, the 
next stage of the research was to identify whether e-commerce had become the preferred channel choice for any particular product category. The research asked individuals to detail how regularly they bought key items from the main town, via the internet and during visits to the mainland $d^{\mathrm{iii}}$ (Table 8). A Friedman test was then conducted to identify whether significant differences existed between frequency of purchase and respondents choice of channel (Table 9). Where differences were noted, a post hoc, Wilcoxon signed rank test with Bonferroni adjustment was applied.

\section{Tables 8 and 9 about here}

The research showed that respondents were most likely to shop in the main town for DIY products, items of furniture and major households appliances (including fridges, cookers and washing machines). In contrast, individuals preferred to travel to the mainland for the purchase of adult and children's clothing and jewellery, (including watches, crystal and glassware). CD's and DVD's were most likely to be bought on-line, while all three channels were equally used for the purchase of electrical and electronic items (including computers, cameras and TV's).

These findings may reflect the high transport costs associated with the delivery of heavy or bulky items (such as furniture) to the islands as well as a tendency to use local retailers for 'essential' household goods that often require immediate replacement (such as fridges / washing machines). Previous research also identified a preference to draw upon local DIY expertise when undertaking complex, project orientated activities (FREATHY and CALDERWOOD, 2013). In contrast, respondents considered the main town as the least preferable option for the purchase of clothing, jewellery and CD/DVDs. For example, over 
$21 \%$ of respondents said that they never purchased any items of adult clothing from the main town, preferring to shop on-line or buy during mainland visits.

The reasons for channel choice were further explored during the qualitative research phase. Individuals identified price, convenience and choice as determining factors for using the internet. As one respondent commented:

"You can find nearly anything online on Amazon which is what I use a lot. I use Amazon for nappies, baby wipes and you can get it all delivered in bulk so it ends up being cheaper.....It is brilliant".

Similarly:

"I can now buy when it is convenient, for example, the town centre supplier of seed potatoes could not supply them until February but they could be sourced for immediate delivery via the internet."

The preference to shop on the mainland reflected the limited product choice available in the main town. For example, while some individuals were happy to purchase clothing over the internet, others preferred to physically see the products prior to purchasing. As one resident noted:

"I would never buy clothes on Shetland as they would never have anything that fits and the clothes that they have are horrendous.... They never seem to have anything nice. My two daughters come back from trips to the mainland with suitcases full of stuff, because they can.... They will buy five things rather than just one. The free boat trips and lack of any limits on what you bring back encourages them to go mad."

Given the preference of individuals to purchase particular products on-line, the research examined how goods and services ordered via the internet were delivered to island households. Four primary methods were identified (Figure 1). These ranged from the retailer delivering directly to the customer (Method One) to more complex procedures that involved goods being first sent to family and friends on the mainland before being collected by an island courier or forwarded via Royal Mail. (Method Four). This latter approach was most 
commonly used when a retailer did not deliver to an island address or added supplementary charges to the cost of carriage.

Figure 1 about here

A number of island couriers had depots on the mainland and were also able to offer a range of service options. For example, if a retailer did not deliver to the islands, customers could arrange to have the product sent to the courier's mainland depot. Items were then transported back to the islands where they could be either collected or delivered to the recipients home (Method Two). In one instance, an island courier had chosen to manage the entire process and offered a service that included the ordering, collecting and delivering of goods from the mainland (Method Three).

While for a number of product categories residents were able to exercise a degree of choice over which channel they used, when shopping for perishable grocery items (such as fresh and chilled goods) they had little alternative other than to use the physical stores on the island. While national grocery multiples operated across all three island groups they are confined almost exclusively to the main town and, at the time of the research, did not offer an on-line service to island residents. One retailer provided a home delivery service (on the main isle) where customers could have shopping delivered to their home. Orders however could not be placed electronically and customers were required to physically visit the stores. In these circumstances internet availability did little to assist residents with their purchase of perishable grocery items and individuals were required to either physically visit a store or rely upon alternative retail channels (such as a mobile shop). 
Consumer choice was further constrained by the spatial distribution of retail stores across the islands For example, on Lewis/Harris in the Outer Hebrides no national grocery multiples operated outside of the main town (Stornoway). Similarly, on the Orkney islands, national multiples operated only two supermarkets outside of Kirkwall (Stromness and Dounby) with grocery provision in rural areas primarily being provided by small, independent retailers, post offices and petrol stations (Figure 2). These outlets were often specialists (e.g. butcher / baker) or limited line grocers with a narrow range products that were typically more expensive than in the main town (Table 2).

\section{Figure 2 about here}

Previous research identified dissatisfaction with the local grocery provision on the islands and a preference to travel to the main town in order to shop (FREATHY and CALDERWOOD, 2013; SHETLAND ISLANDS COUNCIL, 2004). This was also affirmed in this study. For the majority of respondents, the primary reason for shopping in the town was to purchase groceries. Across all island types, $79 \%(n=303)$ undertook their primary grocery shop in the urban centre with over $32 \%$ of all respondents $(n=126)$ travelling over 11 miles. For those individuals living on Type Two and Three islands, travel to the main town can represent a significant undertaking. For example, boat trips between North Ronaldsay and Kirwall (the main town) average two hours forty minutes while a trip from Papa Westray can take over three hours. Despite this, the findings confirm that the majority of island residents chose to undertake their primary shop in the main town rather than use local stores.

Previous research has argued that e-commerce represents an additional retail channel that does not act as a substitute for physical shopping. Individuals derive pleasure from actually 
visiting stores and the impact upon the retail centre remains modest (SIM and KOI, 2002). Positive perceptions of a location may therefore encourage spending and mediate the amount of revenue lost through other channels. Within an island environment this remains particularly important. A strong and vibrant retail economy that has proactively responded to the competitive challenges posed by e-commerce may serve to minimise levels of outshopping and as a consequence reduce the amount of income lost through 'trade leakage' (COURTNEY et al., 2008; LEE at al., 2009).

Respondent views of the retail offer in the town centre however revealed a degree of indifference and ambivalence. Only $44 \%$ maintained that they liked to visit in order to browse the shops while over $61 \%$ said they travelled to the town only to purchase specific items. Such findings do little to support island town centres as primary shopping destinations and the research therefore examined respondent views of the local retail provision. Respondents held varied and somewhat contradictory views with regards to island retailers. While on the one hand the majority of individuals considered it important to support local retailers $(77 \%)$, other views of the current retail offer were less supportive (Table 9).

\section{Table 9 about here}

The majority of island residents felt that local retailers offered good levels of customer service and almost half maintained that they would get better levels of sales support than if they bought direct from the mainland. However the majority of respondents did not consider local retailers to be price competitive, have good product availability, offer unique products or to have responded well to the challenges posed by the internet. 
These issues were further explored during the qualitative research phase. Consumer support for local retailers had in-part been prompted by a growing awareness of the implications of not supporting the town and local shops. For example, in the Shetland isles a series of advertising campaigns had stressed the consequences of not shopping locally and as one respondent noted, "People have been told, use the town centre or lose it". However, despite the willingness of residents to support local businesses, it was still felt that many island retailers had been slow to respond to the competitive threat of the internet. As one individual commented:

"they are living in a different time zone and are not up to date ... they lack the exposure to the new (digital) world .... I think that they are still reliant upon the fact that the elderly or the ageing population will do their shopping in town. I don't think they are really that concerned yet about the internet generation"

While the national multiple operators (Tesco, Co-operative, Boots etc.) all had an on-line presence (with varying levels of service to the isles), the overwhelming majority of respondents could not name a local retailer who operated a transactional website. Those who were able to identify a local site either stated that it was "very basic", "outdated" or used it only to purchase specific items (e.g. Hebridean jewellery, Stornoway black puddings). There was no evidence to suggest that island residents incorporated local web-sites into their regular on-line purchasing behaviour.

Respondents were asked to expand upon the quantitative findings and comment upon the level of retail provision in the town centres. Individuals were critical of the range of shops and maintained that the limited choice had resulted in low expectations. As one resident commented: 
"I just don't go. Well, the only reason I would go on the main street in the town would be to visit the bank or the chemist. There is very little in the town that meets my requirements, because of the range.

Even those individuals who made a conscious effort to use local retailers often found it difficult to support them. For example:

"there is a perpetual case of being torn between trying to support local shops and getting better prices online. Personally I would be happy to pay a tiny bit more to shop locally but often you cannot get something that you specifically want".

The limitations stemming from the range of shops in the town was further compounded by a perceived lack of differentiation amongst those who continued to trade. As one respondent noted:

"There are an awful lot of shops who sell an awful lot of the same things. I think that if one shop is selling it, then you find there will be another shop that sells it. It is a bit of a copycat syndrome in the town and I don't know whether it is because these are mainly shops whose main market are tourists and just buy all the tourist stuff in. It is all much of a sameness."

As Table 6 indicated, respondent views of retail service were mixed and this was reinforced during the in-depth interviews. A number of individuals felt that historically, service levels in many shops had been poor with staff unwilling or unable to respond to local needs. One respondent summed up the general view of service:

"you are in Shetland and this is the only place that you can go to get it, so take what we give you or just forget about it".

However the findings also suggest that this attitude may be changing. A number of individuals maintained that they had seem a demonstrable shift in attitude amongst shop staff. As one respondent reflected: 
"they are better than they used to be, it used to be when you went in some of them could hardly be bothered to talk to you. I think maybe because Tesco's have come and they have clothes and they have electrical items and they have DVDs and all that kind of thing and toys. It is all the one thing under one roof.... when they first came it was very tempting to go there and do all your shopping but I find now that if you go to the smaller shops they are very "can I help you?" and "is there anything that I can do?". They are much more pleasant, much more user friendly than they were eighteen months ago. I would say their attitude has changed and there has been a big campaign about keeping local shops, going to your smaller shops in the town centre and looking at what they have before going to Tesco to buy".

Overall, the above findings suggest that while some retailers have attempted to respond to the competitive threats posed by the national multiples, the majority have (in the opinion of respondents) failed to react to the challenges posed by e-commerce.

\section{Conclusions}

Internet availability on the Scottish isles has reconfigured the shopping behaviour of island residents. The high levels of broadband connectivity appears to have overcome the operational constraints associated with traditional dial up services and the results confirm that e-commerce has become an established retail channel through which a broad range of goods and services are purchased. More fundamentally, the findings illustrate an increasingly dichotomous set of retailer - consumer relationships. Meeting customer demand no longer requires a physical presence on the islands and in many instances can be satisfied irrespective of local retail provision. While the internet has been embraced by residents and championed as a 'liberating mechanism' for the consumer (FREATHY AND CALDERWOOD, 2013), the resultant changes in shopping behaviour has had an impact upon both islands businesses as well as the towns themselves. In this final section the implications of e-commerce for both retailers and the island towns will be considered. 
The findings confirm that e-commerce is used in addition to other forms of shopping channel and, while providing consumers with choice, availability and convenience, its growth and development represents a further competitive threat to the local retail economy. While consumers are more likely to purchase particular products on-line, no category was unaffected by the growth of e-commerce. Despite this, there is little to suggest that local retailers have reacted to such developments or have capitalised upon the opportunities that ecommerce may bring. While there was some noted reaction to the threat of the national grocery multiples, there was little to suggest a proactive response to the challenges posed by on-line providers.

The contention of GALLOWAY et al. (2011) that many rural businesses have not taken full advantage of technological innovations and do not exploit the benefits of ICT, appears to have some justification. While the opportunity to use the internet to develop a global presence may be limited, the same technology provides a means of better serving the local market. On the basis of this research however, there is little evidence to suggest that island residents use local retail web-sites and those who do, tend to purchase specific items. The findings from this study indicate that the overwhelming majority of on-line purchases are not placed with island retailers.

The primary motive for shopping in the town centre was the need to purchase grocery products. This was prompted by the limited distribution of stores across the islands, productprice differentials as well as the lack of an on-line grocery service. While there was a stated desire to support local retailers, this was tempered with an overall feeling that the sector could significantly improve its offer to the customer. The majority of respondents considered 
that retailers in the town centre lacked differentiation, had limited availability and were not competitively priced. These stores were primarily used for the purchase of specific items and appear to benefit from their spatial proximity to the national grocery multiples. Such findings would suggest an inherent vulnerability in the structure and composition of the islands retail sector and that as a shopping destination, the islands towns offer only limited appeal for many residents.

For many consumers the motivations for continuing to frequent the town centres appear primarily functional and do not echo any overwhelming sense of localism or loyalty. As such, town centre patronage is likely to further suffer as patterns of shopping behaviour reflect new technological innovations. For example, the recent announcement by Tesco in Stornoway to start an on-line delivery service in 2014 will represent a further challenge to the sustainability of the main island town. The opportunity for residents "to do a weekly shop from the comfort of their own home" (STORNOWAY GAZETTE, 2013) suggests a reconfiguration of consumption practices that will further reduce the need to travel to the main town.

In conclusion, this research has identified that while the benefits of e-commerce for island residents may be unassailable, its growth and adoption offer a series of competitive challenges that have received only limited academic attention. Within an island context, the majority of on-line purchases represent a form of 'outshopping' that impacts upon both local firms and the physical environment within which they are located. E-commerce does little to stem rural economic decline and serves to further reinforce the fragility of the Scottish isles. While the scale and scope of any trade leakage has yet to be estimated, it is apparent that the 
impact of on-line shopping extends beyond the retail sector and gives rise to a broader series social and economic issues for the island regions. 
Acknowledgements

This work was supported by the British Academy under Grant number SG 112259. 
References

ARMSTRONG, H., JOHNES, G. and MCBEAN, A. (1991) Consumer Goods and Energy Prices on the Isle of Man, Management Research News; 14 (7) 31-35

BINET, T. and WILSON, N. (1997), Developing niche product supply chains in the UK grocery market: lessons from a niche player, Supply Chain Management: An International Journal 2, no.1: 7-10.

BOYLE, P. (1997) Contrasting English and Scottish residents in the Scottish Highlands and Islands, Scottish Geographical Magazine, 113:2, 98-104

BROADBRIDGE and CALDERWOOD, E. (2002) Rural grocery shoppers: do their attitudes reflect their actions? International Journal of Retail and Distribution Management, 30 (8) pp. 394-406.

BYROM, J., MEDWAY, D. and WARNABY, G. (2003) Strategic alternatives for small retail businesses in rural areas, Management Research News; 26 (7) 33-49.

BYROM, J., MEDWAY, D. and WARNABY, G. (2001) Issues of provision and "remoteness" in rural food retailing: A case study of the Southern Western Isles of Scotland, British Food Journal, 103 (6) 400-413

CALDERWOOD, E. and FREATHY, P. (2011) Challenges in the supply of perishable products to island communities, The International Review of Retail, Distribution and Consumer Research, 21(2) 145 - 160

CALDERWOOD, E. and DAVIES, K. (2012), The trading profiles of community retail enterprises, International Journal of Retail \& Distribution Management, 40 (8) pp. 592 - 606. 
CARNEGIE UK (2008) Bearing Fruit- Good Practice in asset-based rural community development, Development Trusts Association, Carnegie Trust UK, Dunfermline

CARNEGIE UK (2007) A Charter for Rural Communities- The final report of the Carnegie Commission for Rural Community Development, Carnegie Trust UK, Dunfermline

COMMISSION FOR RURAL COMMUNITIES. (2006) 'Rural Disadvantage, Reviewing the Evidence'. London: Commission for Rural Communities.

COPUS, A. and CRABTREE, B. (1992) Mapping Economic Fragility: an Assessment of the Objective 5b Boundaries in Scotland, Journal of Rural Studies, 8 (3) pp. 309-322.

COPUS, A. and CRABTREE, J. (1996) Indicators of Socio-Economic Sustainability: An Application to Remote Rural Scotland, Journal of Rural Studies, 12, (1) pp. 41-54.

COURTNEY, P., LE’PICIER, D. and Schmitt, B. (2008) Spatial Patterns of Production Linkages in the Context of Europe's Small Towns: How Are Rural Firms Linked to the Local Economy? Regional Studies, 42 (3) pp. 355-374.

FREATHY, P. and CALDERWOOD, E. (2013) The impact of internet adoption upon the shopping behaviour of island residents, Journal of Retailing and Consumer Services, 20 (1) pp. 111-119.

FREATHY, P. and CALDERWOOD, E. (2011) Challenges in the supply of perishable products to island communities, The International Review of Retail, Distribution and Consumer Research, 21(2) 145 - 160. 
GALLOWAY, L. (2007),"Can broadband access rescue the rural economy?", Journal of Small Business and Enterprise Development, 14 (4) pp. 641 - 653

GALLOWAY, L., SANDERS, J. and DEAKINS, D. (2011) Rural small firms' use of the internet: From global to local, Journal of Rural Studies 27 (3) pp. 254 262.

GUILLAUMONT, P. (2010) Assessing the Economic Vulnerability of Small Island Developing States and the Least Developed Countries, Journal of Development Studies, 46 (5), pp. 828-854.

HSIEH, H-F. and SHANNON, S. (2005) "Three Approaches to Qualitative Content Analysis", Qualitative Health Research, 15 (9) 1277-1288.

KEEBLE, D. and TYLER, P. (1995) Enterprising behavior and the urban rural shift, Urban Studies, 32, (6) pp. 975-997.

KILKENNY, M. (2010) Urban/Regional Economics and Rural Development, Journal of Regional Science, 50 (1) pp. 449-470.

LEE, D., PASWAN, A., GANESH, G. and. XAVIER' M. (2009) Outshopping Through the Internet: A Multicountry Investigation, Journal of Global Marketing 22(1) 53 - 66

MCEACHERN M. and WARNABY, G. (2006) Food shopping behaviour in Scotland: the influence of relative rurality, International Journal of Consumer Studies, 30 , 2, pp189-201, 
MALECKI, E. (2003) Digital development in rural areas: potentials and pitfalls Journal of Rural Studies, 19 (2) pp. 201-214.

MOCHRIE, R., GALLOWAY, L. and DONNELLY, E. (2006),"Attitudes to growth and experience of growth among Scottish SMEs", International Journal of Entrepreneurial Behaviour and Research, 12 (1) pp. 7 - 20.

OFT (2012) "Petrol and diesel pricing in the Scottish islands:OFT assessment of the evidence in relation to price differentials between the mainland and Scottish islands" Office of Fair Trading, May, Report number OFT1432, http://www.oft.gov.uk/shared_oft/marketswork/OFT1432.pdf last accessed 31st October 2012.

PRENTICE, R. (1992) 'Out-shopping' and the externalisation of the Isle of Man retailing economy, Scottish Geographical Magazine, 108 (1) pp.17 - 21.

RAO HILL, S., BURGAN, B. and TROSHANI, I. (2011) Understanding broadband adoption in rural Australia, Industrial Management \& Data Systems, 111 (7), pp.1087 - 1104.

RICHARDS, C. (2004) Information technology and rural development, Progress in Development Studies 4,3 pp. 230-244.

ROBERTS, D. (2005) The role of households in sustaining rural economies: a structural path analysis, European Review of Agricultural Economics, 32 (3) pp. 393-420. 
ROBERTS, D. and THOMSON, K. (2003) Sources of Structural Change in Peripheral Rural Areas: The Case of the Western Isles, 1988/89 to 1997 Regional Studies 37 (1) pp. 61-70

RURAL DEVELOPMENT COMMISSION (1994) Village Shops Mean Business, Rural Development Commission, Salisbury.

SAC (2012) Rural Scotland in Focus, Rural Policy Centre, Scottish Agricultural College.

SCARPELLO, T., POLAND, F., LAMBERT, N. and WAKEMAN, T. (2009) A qualitative study of the food-related experiences of rural village shop customers, Journal of Human Nutrition and Dietetics 22, pp. 108-115.

SCOTTISH EXECUTIVE (2001) 'Digital Inclusion: connecting Scotland's people' Scottish Executive Enterprise and Lifelong Learning Department, Crown Copyright, available at: http://www.scotland.gov.uk/Resource/Doc/158435/0042935.pdf last accessed 2nd November 2012.

SCOTTISH GOVERNMENT (2008) Highlands \& Islands Scotland: European Regional Development Fund 2007-2013 structural funds operational programme, Edinburgh, Scottish Government.

SCOTTISH GOVERNMENT (2010) Socio-Economic Briefing on Rural Scotland: Identifying Fragile Rural Areas Paper 5 Supporting Evidence Provided to the Rural Development Council Working Group, Crown Copyright, available at: http://www.scotland.gov.uk/Resource/Doc/320175/0102396.pdf last accessed 1st November 2012. 
SCOTTISH GOVERNMENT (2012) Scottish Government Urban Rural Classification 20112012, available at:

http://www.scotland.gov.uk/Topics/Statistics/About/Methodology/UrbanRuralClassification/ Urban-Rural-Classification-2011-12 last accessed 11th February 2013.

SELVADURAI, S., MOORTHY, R., LYNDON, N. and ER, A. (2011) Persistence of Traditional Retailing in an Island Town, American Journal of Economics and Business Administration 3 (3) pp.450-455.

SHETLAND ISLANDS COUNCIL (2004) Shetland Islands Shopping Survey 2003, Shetlands Islands Council

SIM, L. and KOI, S. (2002) Singapore's Internet shoppers and their impact on traditional shopping patterns, Journal of Retailing and Consumer Services, 9(2). 115-124.

STOCKDALE, A., (2010) The diverse geographies of rural gentrification in Scotland, Journal of Rural Studies, 26 (1) pp 31 - 40.

STOCKDALE, A., FINDLAY, A and SHORT, D. (2000) The repopulation of rural Scotland: opportunity and threat, Journal of Rural Studies, 16 (2) pp 243 - 257

STORNOWAY GAZETTE (2013) Tesco to introduce online grocery shopping, http://www.stornowaygazette.co.uk/news/local-headlines/tesco-to-introduce-online-groceryshopping-1-3147092 (last accessed 4th December 2013). 
VAN LEEUWEN, E. and RIETVELD, P. (2011) Spatial Consumer Behaviour in Small and Medium-sized Towns, Regional Studies, 45 (8) pp. 1107-1119.

VERHOEF, P. and LANGERAK, F. (2001) Possible determinants of Consumers' adoption of electronic grocery shopping in the Netherlands, Journal of Retailing and Consumer Services, $8(5) 275-285$.

WEBBER, N., CURRY, N. and PLUMRIDGE, A. (2009) Business Productivity and Area Productivity in Rural England, Regional Studies, 43 (5), pp. 661-675. 
Table 1: Number of retailers in each town by category

\begin{tabular}{|c|c|c|c|}
\hline & \multicolumn{3}{|c|}{ Town } \\
\hline Product Category & $\begin{array}{l}\text { Kirkwall } \\
\text { (Orkney) }\end{array}$ & $\begin{array}{l}\text { Lerwick } \\
\text { (Shetland) }\end{array}$ & $\begin{array}{l}\text { Stornoway } \\
\text { (Outer Hebrides) }\end{array}$ \\
\hline Bikes & 1 & 2 & 1 \\
\hline Books $^{\mathrm{a}}$ & 3 & 2 & 4 \\
\hline Car Accessories / Tyres & 3 & 1 & 1 \\
\hline Camera / Photographic & 1 & 2 & 1 \\
\hline Card Shops & 1 & 3 & 1 \\
\hline Charity & 4 & 9 & 9 \\
\hline Chemists / Cosmetics / Toiletries & 2 & 3 & 3 \\
\hline Clothing \& Footwear (Adults) & 11 & 14 & 12 \\
\hline Clothing and Footwear (Children) & 1 & 2 & 1 \\
\hline Computer / Office Supplies & 3 & 1 & 2 \\
\hline DIY / Paint / Hardware & 4 & 3 & 3 \\
\hline Electrical & 2 & 4 & 2 \\
\hline Florists & 2 & 2 & 2 \\
\hline Furniture & 2 & 1 & 3 \\
\hline Gifts / Arts / Crafts & 11 & 12 & 10 \\
\hline Grocery / Food ${ }^{\mathrm{b}}$ & 16 & 23 & 14 \\
\hline Healthfood & 0 & 2 & 1 \\
\hline Home and Garden & 3 & 2 & 3 \\
\hline Jewellery & 4 & 3 & 3 \\
\hline Kitchen \& Bathrooms & 2 & 1 & 1 \\
\hline Luggage & 0 & 1 & 0 \\
\hline Music / CD / DVD & 2 & 1 & 0 \\
\hline Newsagents & 2 & 2 & 3 \\
\hline Opticians & 2 & 3 & 2 \\
\hline Pets & 1 & 2 & 0 \\
\hline Sports & 1 & 2 & 1 \\
\hline Toys & 1 & 1 & 1 \\
\hline Variety / Dept Store / General Merchant & 3 & 1 & 4 \\
\hline
\end{tabular}

${ }^{a}$ Includes second hand and Christian bookshops

${ }^{\mathrm{b}}$ Grocery / food retailers, includes national multiples as well as delicatessens, frozen food outlets and independent specialists (butchers bakers etc) 
Table 2: Price comparison for selection of ambient branded products

\begin{tabular}{|c|c|c|c|c|c|c|}
\hline \multirow[t]{2}{*}{ PRICE COMPARISON (£) } & & \multicolumn{3}{|c|}{ On-line } & \multirow{2}{*}{$\begin{array}{c}\text { National } \\
\text { Multiple } \\
\text { Unit } \\
\text { Retail } \\
\text { Price }\end{array}$} & \multirow{2}{*}{$\begin{array}{c}\text { Independent } \\
\text { Unit Retail } \\
\text { Price }\end{array}$} \\
\hline & & $\begin{array}{l}\text { Case } \\
\text { Price }\end{array}$ & $\begin{array}{l}\text { Packs } \\
\text { per } \\
\text { unit }\end{array}$ & $\begin{array}{c}\text { Unit } \\
\text { Retail } \\
\text { Price }\end{array}$ & & \\
\hline Ritz Crackers & $200 \mathrm{~g}$ & 9.00 & 12 & 0.75 & 1.29 & 1.30 \\
\hline Fairy NonBio Powder & $3.04 \mathrm{~kg}$ & 10.50 & 1 & 10.50 & 10.50 & 12.99 \\
\hline Felix As Good as it Looks & $12 \times 100 \mathrm{~g}$ & 12.00 & 4 & 3.00 & 4.88 & 5.50 \\
\hline Baxters soups & $400 \mathrm{~g}$ & 8.04 & 12 & 0.67 & 1.04 & 1.30 \\
\hline Bonne Maman Strawberry conserve & $370 \mathrm{~g}$ & 8.76 & 6 & 1.46 & 2.19 & 2.75 \\
\hline $\begin{array}{l}\text { Sharwoods Ready to Wok Noodles } \\
\text { medium }\end{array}$ & $300 \mathrm{~g}$ & 6.36 & 6 & 1.06 & 1.59 & 2.15 \\
\hline Twinings English Breakfast & $50 \mathrm{~s}$ & 9.96 & 4 & 2.49 & 3.69 & 2.95 \\
\hline Whiskas pouches & 12pack & 10.00 & 4 & 2.50 & 3.68 & 4.30 \\
\hline Nutella & $200 \mathrm{~g}$ & 15.00 & 15 & 1.00 & 1.36 & 1.50 \\
\hline Rowse Squeezy Clear Honey & $340 \mathrm{~g}$ & 12.00 & 6 & 2.00 & 2.59 & 2.80 \\
\hline Twinings Fruit Teabags & 20 pack & 8.00 & 8 & 1.00 & 1.29 & 1.75 \\
\hline Pot Noodles & $117 \mathrm{~g}$ & 12.32 & 12 & 1.03 & 1.25 & 1.25 \\
\hline Andrex Toilet Tissues & 9 rolls & 18.75 & 5 & 3.75 & 4.49 & 5.95 \\
\hline Weetabix & $24 \mathrm{~s}$ & 12.00 & 6 & 2.00 & 2.39 & 3.00 \\
\hline Scotts Porridge Oats & $1 \mathrm{~kg}$ & 21.00 & 12 & 1.75 & 2.09 & 2.45 \\
\hline Kelloggs Crunchy Nut Cornflakes & $500 \mathrm{~g}$ & 13.25 & 5 & 2.65 & 2.69 & 3.50 \\
\hline Rowse Pure and Natual honey & $340 \mathrm{~g}$ & 7.77 & 3 & 2.59 & 2.59 & 2.80 \\
\hline Douwe Egberts Coffee & $190 \mathrm{~g}$ & 13.18 & 2 & 6.59 & 6.59 & 8.35 \\
\hline Cadbury drinking chocolate & $500 \mathrm{~g}$ & 8.97 & 3 & 2.99 & 2.99 & 2.25 \\
\hline Seeds of Change Spaghetti & $500 \mathrm{~g}$ & 21.00 & 12 & 1.75 & 1.75 & 2.00 \\
\hline Heinz Tomato sauce & $460 \mathrm{~g}$ & 18.50 & 10 & 1.85 & 1.85 & 2.25 \\
\hline Nairns Organic Oatcakes & $250 \mathrm{~g}$ & 13.08 & 12 & 1.09 & 1.09 & 1.25 \\
\hline Mackays Raspberry Preserve & $340 \mathrm{~g}$ & 9.00 & 6 & 1.50 & 1.49 & 1.55 \\
\hline Pataks Tandoori Curry Paste & $312 \mathrm{~g}$ & 11.94 & 6 & 1.99 & 1.8 & 2.10 \\
\hline Heinz Spaghetti Hoops & $400 \mathrm{~g}$ & 19.78 & 24 & 0.82 & 0.6 & 0.90 \\
\hline Vanish Oxi Action Powder & $2 \mathrm{~kg}$ & 17.99 & 5 & 3.60 & 8.70 & 8.99 \\
\hline Kraft Macaroni and Cheese & $205 \mathrm{~g}$ & 5.49 & 3 & 1.83 & 2.2 & 1.50 \\
\hline Yorkshire Teabags & $250 \mathrm{~g}$ & 13.31 & 5 & 2.66 & 2.49 & 2.95 \\
\hline Tabasco sauce & $60 \mathrm{ml}$ & 24.60 & 12 & 2.05 & 1.89 & 2.15 \\
\hline Nescafe original & $100 \mathrm{G}$ & 39.99 & 12 & 3.33 & 2.79 & 3.10 \\
\hline Fairy Liquid Lemon & $433 \mathrm{ml}$ & 16.39 & 10 & 1.64 & 1.25 & 1.50 \\
\hline Febreeze Classic & $500 \mathrm{~g}$ & 4.07 & 1 & 4.07 & 2.99 & 3.25 \\
\hline Nescafe Gold Blend coffee & $100 \mathrm{G}$ & 29.89 & 6 & 4.98 & 3.34 & 3.10 \\
\hline HP Squeezy Brown Sauce & $850 \mathrm{G}$ & 35.50 & 8 & 4.44 & 2.79 & 3.50 \\
\hline Frosties & $500 \mathrm{~g}$ & 22.99 & 5 & 4.60 & 2.29 & 3.25 \\
\hline Johnsons Baby Powder & $500 \mathrm{ml}$ & 2.99 & 1 & 2.99 & 1.39 & 1.45 \\
\hline Lea and Perrins Worcestershire Sauce & $150 \mathrm{~g}$ & 15.99 & 6 & 2.67 & 1.19 & 2.75 \\
\hline Total & & 539.36 & & 97.63 & 101.07 & 116.38 \\
\hline
\end{tabular}


Table 3: Island Types

\begin{tabular}{|l|l|l|}
\hline Type & Criteria & Examples \\
\hline One & $\begin{array}{l}\text { Has at least one established retail centre } \\
\text { with national retail multiples present }\end{array}$ & $\begin{array}{l}\text { Isle of Lewis and Harris, Orkney, } \\
\text { Shetland Mainland }\end{array}$ \\
\hline Two & $\begin{array}{l}\text { Islands with retail presence but no } \\
\text { national multiple retailer }\end{array}$ & Isle of Ghiga, Isle of Rhum \\
\hline Three & Islands with no formal retail provision & Isle of Muck, Papa Stour \\
\hline
\end{tabular}


Table 4: Questionnaire distribution and returns by island type

\begin{tabular}{|c|c|c|c|c|c|c|}
\hline & $\begin{array}{l}\text { Total } \\
\text { Number } \\
\text { Distributed }\end{array}$ & $\begin{array}{l}\text { Numbers returned by } \\
\text { Island Group }\end{array}$ & (N) & $\begin{array}{l}\text { Numbers retu } \\
\text { by drive time } \\
\text { main town (m }\end{array}$ & & N) \\
\hline $\begin{array}{l}\text { Type } \\
\text { One }\end{array}$ & 1850 & $\begin{array}{l}\text { Orkney } \\
\text { Outer Hebrides } \\
\text { Shetland }\end{array}$ & $\begin{array}{c}92 \\
114 \\
139\end{array}$ & $\begin{array}{l}\text { Urban } \\
10-20 \text { mins } \\
21-30 \text { mins } \\
31-60 \text { mins } \\
60+\end{array}$ & - & $\begin{array}{r}141 \\
74 \\
63 \\
35 \\
32 \\
\end{array}$ \\
\hline $\begin{array}{l}\text { Type } \\
\text { Two }\end{array}$ & 165 & $\begin{array}{l}\text { Orkney } \\
\text { Outer Hebrides } \\
\text { Shetland }\end{array}$ & $\begin{array}{c}12 \\
0 \\
19\end{array}$ & & & \\
\hline $\begin{array}{l}\text { Type } \\
\text { Three }\end{array}$ & 62 & $\begin{array}{l}\text { Orkney } \\
\text { Outer Hebrides } \\
\text { Shetland }\end{array}$ & $\begin{array}{l}8 \\
3 \\
1\end{array}$ & & & \\
\hline Total & & & 388 & & & \\
\hline
\end{tabular}


Table 5: Profile of island respondents

\begin{tabular}{|c|c|c|c|}
\hline Characteristics & Category & $\begin{array}{l}\text { Respondent Profile } \\
\text { (n) }\end{array}$ & $\begin{array}{c}\text { Respondent } \\
\text { Profile } \\
(\%)\end{array}$ \\
\hline \multirow[t]{2}{*}{ Gender } & Male & 123 & 32 \\
\hline & Female & 261 & 68 \\
\hline \multirow[t]{6}{*}{ Age } & $16-24$ & 25 & 6.5 \\
\hline & $25-34$ & 43 & 11.2 \\
\hline & $35-44$ & 61 & 15.8 \\
\hline & $45-54$ & 81 & 21.0 \\
\hline & $55-64$ & 87 & 22.6 \\
\hline & $65+$ & 88 & 22.9 \\
\hline \multirow[t]{6}{*}{ Numbers living in Household } & 1 & 71 & 18.8 \\
\hline & 2 & 168 & 44.4 \\
\hline & 3 & 54 & 14.3 \\
\hline & 4 & 48 & 12.7 \\
\hline & 5 & 31 & 8.2 \\
\hline & $6+$ & 6 & 1.6 \\
\hline \multirow{5}{*}{$\begin{array}{l}\text { Number (living in Household) } \\
\text { aged } 15 \text { or under }\end{array}$} & 0 & 283 & 74.9 \\
\hline & 1 & 43 & 11.4 \\
\hline & 2 & 32 & 8.2 \\
\hline & 3 & 18 & 4.6 \\
\hline & $4+$ & 2 & 0.5 \\
\hline \multirow[t]{6}{*}{ Length of time lived on island } & $<1$ year & 8 & 2.1 \\
\hline & $2-3$ years & 15 & 3.9 \\
\hline & $4-5$ years & 16 & 4.1 \\
\hline & $6-10$ years & 35 & 9.0 \\
\hline & $11-20$ years & 49 & 12.7 \\
\hline & $20+$ years & 264 & 68.2 \\
\hline
\end{tabular}


Table 6: Number of individuals interviewed by island type

\begin{tabular}{|l|l|l|l|}
\hline & Type One & Type Two & Type Three \\
\hline Shetland & 10 & 3 & 1 \\
\hline Orkney & 10 & 2 & 1 \\
\hline Outer Hebrides & 11 & & 1 \\
\hline
\end{tabular}


Table 7: Respondent travel and on-line purchase frequency

\begin{tabular}{|c|c|c|c|}
\hline & Frequency & $(\mathrm{n})$ & $(\%)$ \\
\hline \multicolumn{4}{|l|}{$\begin{array}{l}\text { Internet used to gather } \\
\text { information over past month }\end{array}$} \\
\hline & Not searched on line in last 4 weeks & & \\
\hline & $1-3$ purchases & & \\
\hline & $4-7$ purchases & & \\
\hline & $8-11$ purchases & & \\
\hline & $11+$ purchases & & \\
\hline \multicolumn{4}{|l|}{$\begin{array}{l}\text { Frequency of on-line purchases } \\
\text { over past month }\end{array}$} \\
\hline & Not purchased in last 4 weeks & 55 & 14.5 \\
\hline & $1-3$ purchases & 145 & 38.2 \\
\hline & $4-7$ purchases & 108 & 28.4 \\
\hline & $8-11$ purchases & 40 & 10.5 \\
\hline & $11+$ purchases & 32 & 8.4 \\
\hline \multicolumn{4}{|l|}{$\begin{array}{l}\text { Frequency of shopping visits to } \\
\text { Main Town }\end{array}$} \\
\hline & Every Day & 24 & 6.2 \\
\hline & At least twice a week & 164 & 42.5 \\
\hline & Once a week & 106 & 27.5 \\
\hline & Once a fortnight & 32 & 8.3 \\
\hline & Once a month & 37 & 9.6 \\
\hline & Less than once a month & 14 & 3.6 \\
\hline & Do not travel to the main town to shop & 9 & 2.3 \\
\hline \multicolumn{4}{|l|}{ Frequency of visits to Mainland } \\
\hline & Once a week & 1 & 0.3 \\
\hline & Once a fortnight & 3 & 0.8 \\
\hline & Once a month & 32 & 8.3 \\
\hline & Once every six months & 227 & 59.1 \\
\hline & Once a year & 81 & 21.1 \\
\hline & Less than once a year & 40 & 10.4 \\
\hline
\end{tabular}


Table 8: Channel through which products most likely to be purchased

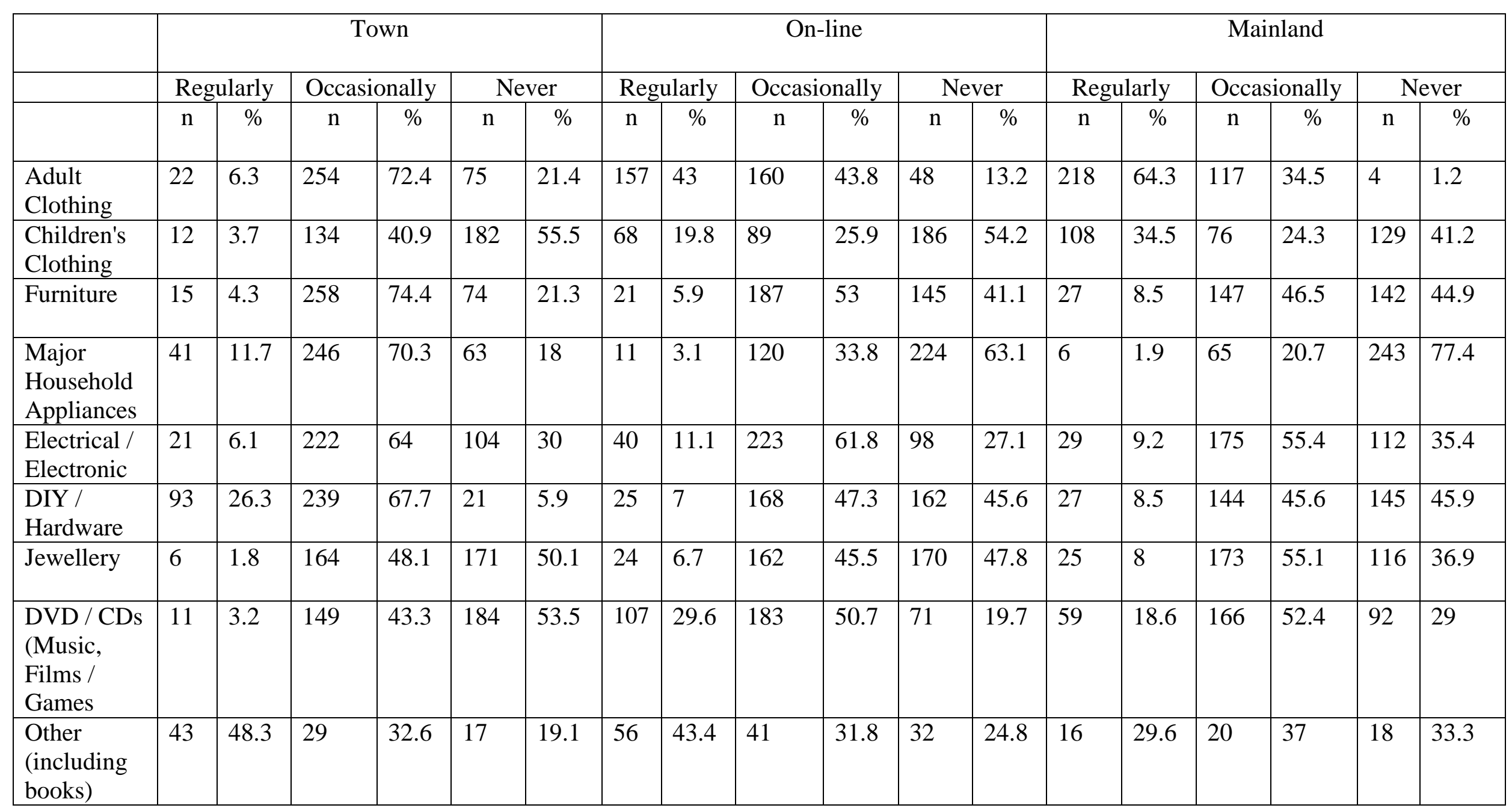


Table 9: Channel preferences for different product categories

\begin{tabular}{|c|c|c|c|c|c|c|c|c|c|c|}
\hline & \multicolumn{4}{|c|}{ Friedman Test } & \multicolumn{6}{|c|}{ Wilcoxon signed rank test } \\
\hline & & & & & $\begin{array}{r}\text { Town } \\
\text { lin }\end{array}$ & On- & $\begin{array}{r}\text { Tow } \\
\text { Main }\end{array}$ & & $\begin{array}{r}\text { Main } \\
\text { On }\end{array}$ & $\begin{array}{l}\text { nd v } \\
\text { ne }\end{array}$ \\
\hline & $\mathrm{N}$ & $\chi^{2}$ & $\mathrm{df}$ & sig & $\mathrm{Z}$ & sig & $\mathrm{Z}$ & sig & $\mathrm{Z}$ & sig \\
\hline Adult Clothing & 301 & 230.062 & 2 & .000 & -8.230 & .000 & 12.947 & .000 & -7.354 & .000 \\
\hline $\begin{array}{l}\text { Children's } \\
\text { Clothing }\end{array}$ & 275 & 177.227 & 2 & .000 & -4.482 & .000 & -9.182 & .000 & -7.759 & .000 \\
\hline Furniture & 284 & 24.68 & 2 & .000 & -4.16 & .000 & -3.867 & .000 & -0.576 & .565 \\
\hline $\begin{array}{l}\text { Major } \\
\text { Household } \\
\text { Appliances }\end{array}$ & 287 & 187.276 & 2 & .000 & -9.094 & .000 & $\begin{array}{c}- \\
11.351\end{array}$ & .000 & -4.043 & .000 \\
\hline $\begin{array}{l}\text { Electrical / } \\
\text { Electronic }\end{array}$ & 289 & 7.841 & 2 & .020 & -1.554 & .120 & -2.18 & .827 & -2.991 & .003 \\
\hline DIY / Hardware & 290 & 168.382 & 2 & .000 & $\begin{array}{r}- \\
11.245\end{array}$ & .000 & -9.876 & .000 & -.509 & .611 \\
\hline Jewellery & 283 & 19.222 & 2 & .000 & -1.686 & .092 & -4.198 & .001 & -3.433 & .001 \\
\hline $\begin{array}{l}\text { DVD / CDs } \\
\text { (Music, Films / } \\
\text { Games }\end{array}$ & 289 & 134.253 & 2 & .000 & $\begin{array}{c}- \\
10.367\end{array}$ & .000 & -7.83 & .000 & -4.996 & .000 \\
\hline $\begin{array}{l}\text { Other (including } \\
\text { books) }\end{array}$ & 30 & 429 & 2 & $.807^{\mathrm{a}}$ & * & * & * & * & * & * \\
\hline
\end{tabular}

a. Wilcoxon post hoc test not conducted when Friedman Test is statistically insignificant 
Table 10: Consumer attitudes towards local retail provision

\begin{tabular}{|l|l|l|l|}
\hline Local Retailers: & Agree (\%) & Disagree (\%) & Neither (\%) \\
\hline Are price competitive & $130(33.9)$ & $145(37.9)$ & $108(28.2)$ \\
\hline Provide good levels of customer service & $211(54.9)$ & $100(26)$ & $73(19)$ \\
\hline Have good availability & $125(32.6)$ & $146(38.1)$ & $112(29.2)$ \\
\hline Understand my shopping needs & $101(26.5)$ & $110(28.9)$ & $170(44.6)$ \\
\hline Have responded well to internet competition & $69(18.2)$ & $171(45)$ & $140(36.8)$ \\
\hline Offer unique products & $70(19.9)$ & $186(53)$ & $95(27.1)$ \\
\hline $\begin{array}{l}\text { Provide better levels of sales support than if } \\
\text { bought direct from the mainland }\end{array}$ & $179(47.2)$ & $87(23)$ & $113(29.8)$ \\
\hline
\end{tabular}


Figure 1: E-commerce delivery methods to island communities

Method 1

\begin{tabular}{|c|c|c|}
\hline \multirow[b]{2}{*}{ Customer } & Delivery & \\
\hline & & Retailer \\
\hline L & Places Order & \\
\hline
\end{tabular}

Method 2

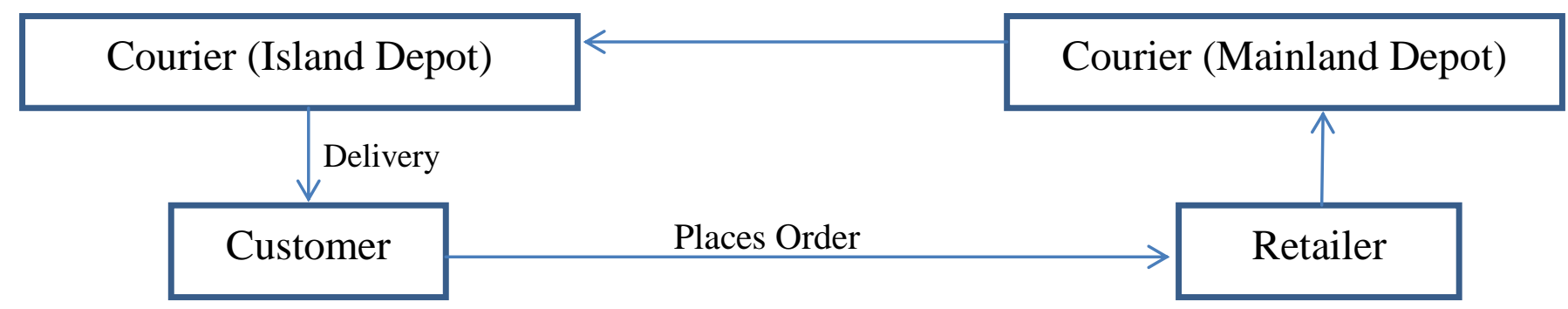

Method 3

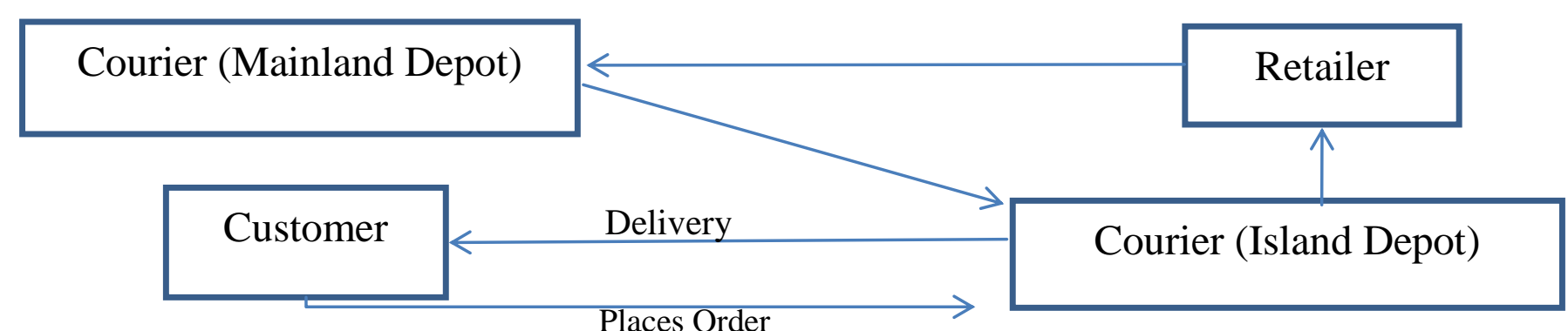

Method 4

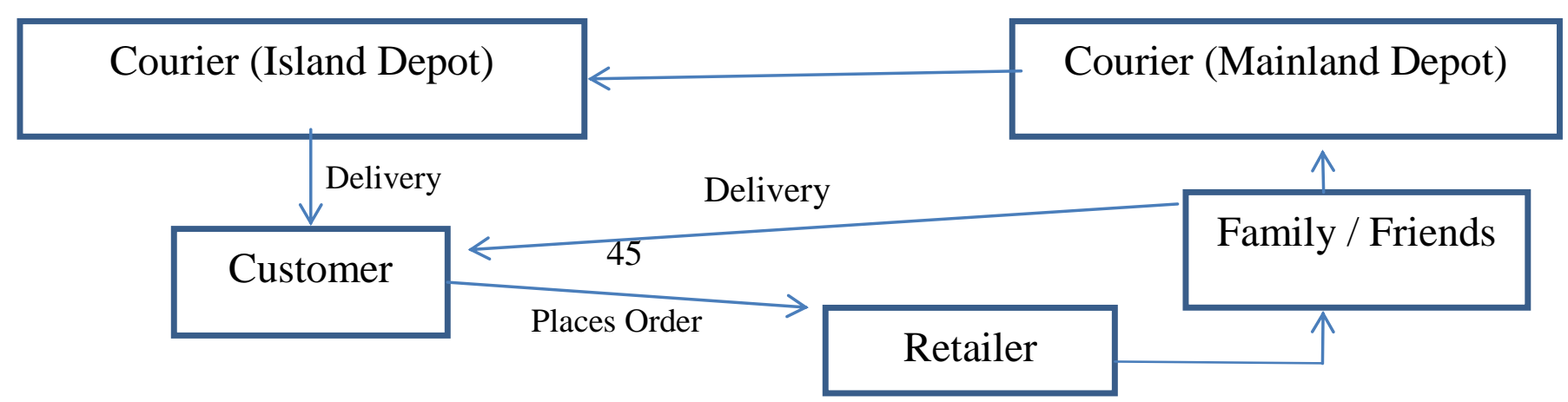


Figure 2: Spatial Distribution of Food Stores on the Orkney Islands
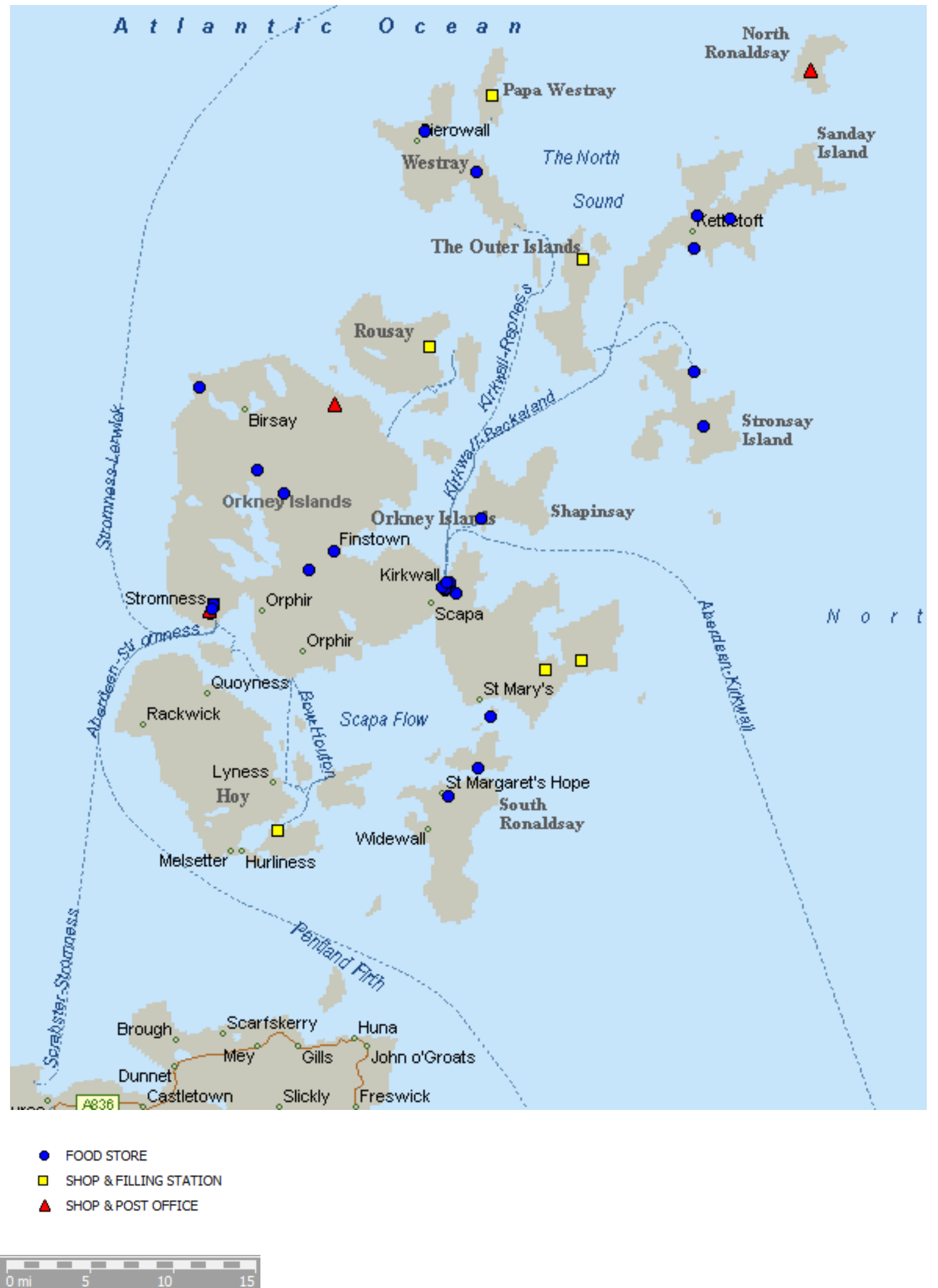


\section{Endnotes}

${ }^{\mathrm{i}}$ Internet growth has been supported by the Scottish Government who have explicitly stated its desire to create a world class digital infrastructure by 2020 (SCOTTISH GOVERNMENT, 2013). While broadband connectivity is seen as essential for both regional development and local economic performance, the Scottish islands have been recognised as a 'white spot' and unlikely to benefit from direct private sector investment due to specific geographical and environmental challenges. As a consequence, the Scottish Government have taken responsibility for digital infrastructure projects on the islands with the explicit aim of achieving $100 \%$ broadband coverage within the next seven years (SCOTTISH GOVERNMENT, 2013).

${ }^{\text {ii }}$ Very remote rural areas are defined as having a drive time of more than 60 minutes from a settlement of more than 10,000 people.

${ }^{\text {iii }}$ Grocery shopping was not included in this analysis as only two respondents $(n=388)$ said that they did not shop in island stores. 